\title{
Five new species of Ectobiidae (Blattodea) collected in the Reserva Ducke, Amazonas, Brazil
}

\author{
Sonia Maria Lopes ${ }^{1,3}$, Edivar Heeren de Oliveira $^{1}$ \& Vitor Tarli ${ }^{2}$ \\ ${ }^{I}$ Departamento de Entomologia do Museu Nacional, Universidade Federal do Rio de Janeiro, \\ Rio de Janeiro, RJ, Brazil. \\ ${ }^{2}$ Instituto Nacional de Pesquisas da Amazonia, Manaus, AM, Brazil. \\ ${ }^{3}$ Corresponding author: Sonia Maria Lopes, e-mail: sonialfraga@gmail.com
}

\begin{abstract}
LOPES, S.M., OLIVEIRA, E.H., TARLI, V. Five new species of Ectobiidae (Blattodea) collected in the Reserva Ducke, Amazonas, Brazil. Biota Neotropica. 14(4): e20130079. http://dx.doi.org/10.1590/167606032014007913
\end{abstract}

\begin{abstract}
Herein we describe five new species of the Ectobiidae subfamilies Pseudophyllodromiinae (Amazonina spiculata sp. nov., Amazonina spinostylata sp. nov., Cariblatta duckeniana sp. nov., Cariblatta manauensis sp. nov.) and Nyctiborinae (Nyctibora nigra sp. nov.), collected in the Reserva Ducke, Manaus, state of Amazonas. The specimens were collected from litter, fallen logs, branches, and foliage. We illustrate the male genitalia of the new species.

Keywords: Blattaria, Nyctiborinae, Pseudophyllodromiinae, Taxonomy, Leaf litter.
\end{abstract}

LOPES, S.M., OLIVEIRA, E.H., TARLI, V. Cinco espécies novas de Ectobiidae (Blattodea) coletados na Reserva Ducke, Amazonas, Brasil. Biota Neotropica. 14(4): e20130079. http://dx.doi.org/10.1590/167606032014007913

Resumo: Neste trabalho são descritas cinco novas espécies das subfamílias Pseudophyllodromiinae (Amazonina spiculata sp. nov., Amazonina spinostylata sp. nov., Cariblatta duckeniana sp. nov., Cariblatta manauensis sp. nov.) and Nyctiborinae (Nyctibora nigra sp. nov.) coletadas na Reserva Ducke, Manaus (Estado do Amazonas). Os espécimens foram coletados em folhiço, troncos caídos, ramos e folhagens. Foram ilustradas as genitálias dos machos das novas espécies.

Palavras-chave: Blattaria, Nyctiborinae, Pseudophyllodromiinae, Taxonomia, Folhiços.

\section{Introduction}

The specimens of Blattodea presented herein were collected in the Reserva Ducke, Manaus, state of Amazonas, and belong to the family Ectobiidae. Most ectobiid species are small in size compared to blaberids and many blattids. They are usually long-legged and very fast-moving (Rentz 2014). Forest ecosystems, such as the area within the Ducke Reserve, have structurally complex habitats where cockroaches are relatively diverse. These habitats offer many niches for roach populations, including living and dead leaves, branches, cracks and spaces in the bark, twigs, hollows, etc. (Bell et al. 2007). In temperate climates, cockroaches play a minor role in soil biology because their populations are not very dense (Eisenbeis \& Wichard 1985). Similarly, in tropical forests, ants, mites and springtails are dominant, and cockroaches are only occasionally mentioned in this context (Fittkau \& Klinge 1973).

In this contribution we describe and illustrate the male genitalia of five new species of Ectobiidae collected in the Reserva Ducke, Manaus, state of Amazonas. Four of the new species belong to the subfamily Pseudophyllodromiinae and one to Nyctiborinae. The Ectobiidae were studied by Khambhampati (1996), based on 31 species of cockroaches and their mitochondrial DNA and RNA concluded that
Ectobiidae is a sister group of Blaberidae. This conclusion was supported by Maekawa \& Matsumoto (1999) after analyzing 18 species of orthopteroid insects, including three species of Asian cockroaches belonging to the families Blaberidae, Ectobiidae and Blattidae, based on COII, and added that Blattidae is a sister-group of the Blaberidae and Ectobiidae.

In the checklist provided by Beccaloni (2014), among Pseudophyllodromiinae, the genus Amazonina Hebard, 1929 comprises 17 species, of which 15 are Neotropical and 14 of these are described from Brazil, in the Amazon region; and the genus Cariblatta Hebard, 1916 comprises 82 Neotropical species, of which 45 are listed for South America, with 42 species in Brazil and seven restricted to the Amazon region. The present study adds two species to each of these genera. The subfamily Nyctiborinae comprises 32 species, of which 29 are Neotropical, including 22 from Brazil with 15 recorded in the Amazon region; an additional species of Nyctibora from the Amazon is added herein.

The diversity of Blattodea is little known. Rocha e Silva Albuquerque (1974) studied members of Amazonina in the Amazon region; Lopes \& Oliveira (2002a) added one species to the genus, and Lopes (2008) presented a new record of the genus for southeastern Brazil Rocha e Silva Albuquerque \& 
Lopes (1975) recorded six species for the Amazon region. Lopes \& Oliveira (2009) recorded two species of Nyctibora, and VélezBravo (2013) recorded six additional species of this genus in the Amazon region. Lopes \& Oliveira (2002b, 2004 and 2005) reported new locality records for members of both genera.

\section{Materials and Methods}

This study was conducted in the dense ombrophilous forest of the Reserva Ducke. The Reserva Ducke is located at km 26 of highway AM-010 (Manaus-Itacoatiara) between $03^{\circ} 00^{\prime} 02^{\prime \prime}$ and $03^{\circ} 08^{\prime} 00^{\prime \prime} \mathrm{S}$ and $59^{\circ} 58^{\prime} 00^{\prime \prime} \mathrm{W}$. The regional climate is type Afi according to the Köppen classification. The mean annual temperature is $25^{\circ} \mathrm{C}$, and the minimum mean monthly temperature never falls below $18^{\circ} \mathrm{C}$. The mean annual rainfall is $2000 \mathrm{~mm}$, with a rainy season from November to May, with most rainfall in March and April; and a dry season from June to October, with September typically the driest month (Sampaio et al. 2005).

The vegetation is typical terra-firme tropical humid forest, which can be differentiated into plateau forest, with predominantly clay soils or dystrophic yellow-alic latosol; forest slope along the transition between the plateau and the valley, with predominantly quartz-sand soils; and campinarana forest or valley, with predominantly sandy soils (Ribeiro et al. 1999).

The collecting focused on adults found in the leaf litter, and on twigs, fallen logs and foliage. We collected during the early evening hours, using a plastic container with $50 \mathrm{ml}$ of $70 \%$ ethanol, to euthanize the specimens. The specimens were placed in plastic containers with $70 \%$ ethanol and $8 \mathrm{ml}$ glycerin in a proportion of 80:20, and were labeled as to collector, date, time of collection and plot number. They were then taken to the laboratory, sorted and pinned. The species were identified at the Museu Nacional of Rio de Janeiro, with the aid of identification keys and comparison with previously identified material. For observation of the genital plates, we separated the tail from the abdomen, using traditional dissection techniques described by Lopes \& Oliveira (2000). After analysis, the plates and genital parts were stored in microtubes containing glycerin, and stored next to their respective specimens, a technique developed by Gurney et al. (1964). The terminology of the genitalia and the taxonomic classification are based on Roth (2003).

We collected a total of 777 specimens of Ectobiidae, of which 359 belong to subfamily Pseudophyllodromiinae, 409 to Blattellinae, 7 to Anaplectinae and 2 to Nyctiborinae. The 5 new species described are represented by 132 specimens belonging to the subfamilies Pseudophyllodromiinae and Nyctiborinae. The remaining 227 individuals are other, known species of Pseudophyllodromiinae.

The material studied in this paper was deposited in the collection of the Instituto Nacional de Pesquisas da Amazônia, INPA and in the collection of the Entomology Department of the Museu Nacional, UFRJ/MN.

\section{Results}

Amazonina spiculata sp. nov.

General coloration dark brown (Figure 6a). Head and interocular space with scattered dark-brown marks, eye black (Figure 1a); antennae and palps pale, golden-tomentose; pronotum indistinctly hyaline; central disk pale brown with

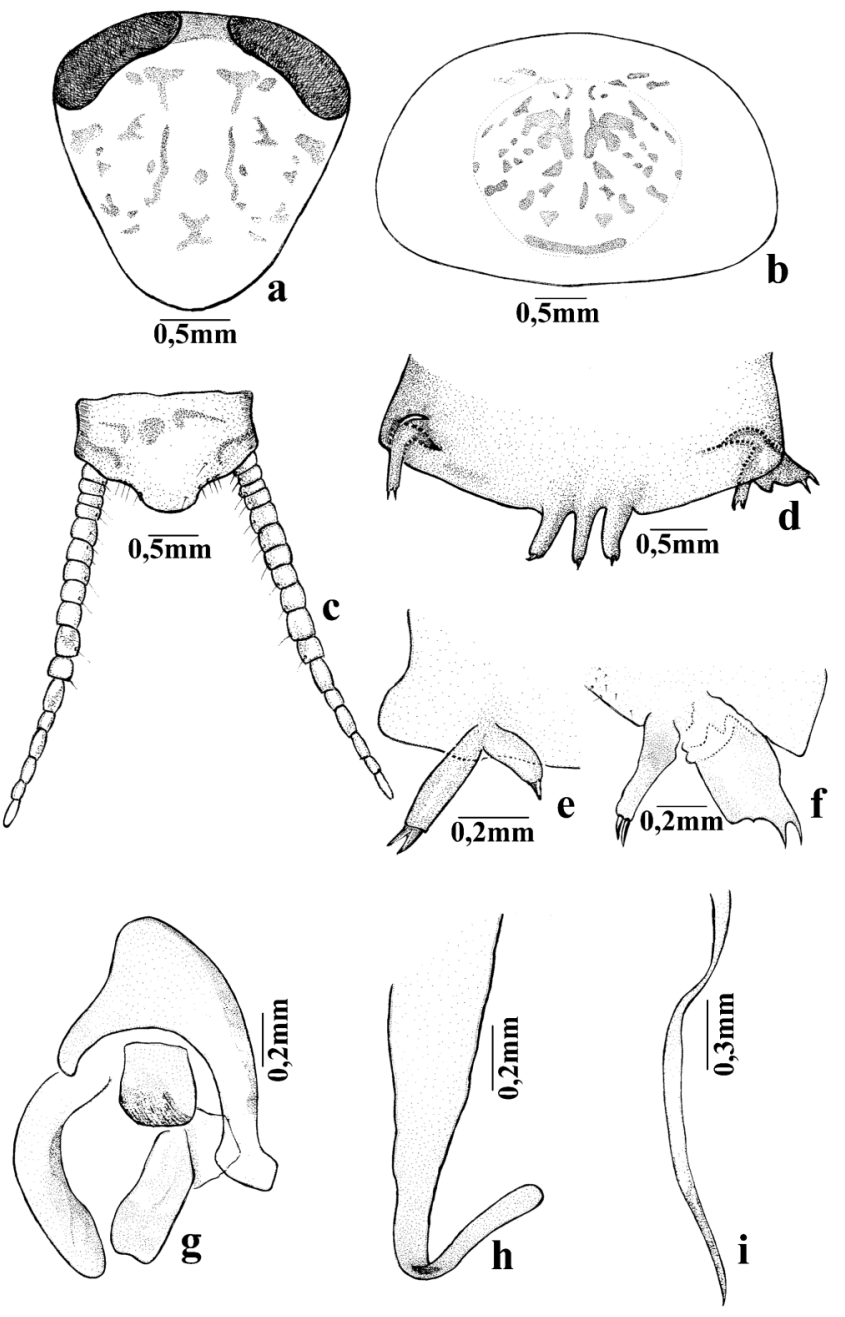

Figure 1. Amazonina spiculata sp. nov., male holotype. a. Head, ventral view; b. pronotum, dorsal view; c. Supranal plate, dorsal view; d. Subgenital plate, ventral view; e. Detail of the lateral base of the subgenital plate with a spiniform structure, left side, ventral view; f. Detail of the lateral base of the subgenital plate with a spiniform structure, right side, ventral view; g. Left phallomere, dorsal view; h. Right phallomere, dorsal view; i. Median sclerite, dorsal view.

dark-brown dots and strokes (Figure 1b); tegmina with sparse dark-brown dots; legs with insertion area of tibial spines dark brown; pulvilli whitish. Wings with dilated apices of radial veins brown.

Dimensions of Holotype ${ }^{\prime}$. Total length: $15.4 \mathrm{~mm}$; length of pronotum: $2.8 \mathrm{~mm}$; width of pronotum: $3.8 \mathrm{~mm}$; length of tegmen: $13.4 \mathrm{~mm}$; width of tegmen: $3.2 \mathrm{~mm}$.

Head subtriangular, vertex slightly exposed beneath pronotum in dorsal view; interocular space narrow, approximately one-third of distance between antennal bases. Antennae long, reaching beyond apex of abdomen; maxillary palps with third and fourth articles similar in size and larger than the dilated fifth article.

Thorax with pronotum subtrapezoidal, lateral flaps rounded and slightly deflexed. Legs spiny; fore femur with ventrocephalic margin bearing row of 12 spines that gradually decrease in size toward the apex, plus two large apical spines; ventrocaudal margin with four well-spaced spines in medianapical region, one apical spine; middle and hind femora each 
with five or six large, well-spaced spines, including one apical spine, similarly arranged on ventral surfaces; genicular spine present; pulvilli present on all tarsomeres, claws symmetrical and specialized; arolium small. Tegmina long, reaching beyond apex of cerci; marginal field narrow. Scapular field elongate, with oblique veins; discoidal field with longitudinal venular arrangement; basal branches arranged almost obliquely; anal field narrow, with 6 or 7 axillary veins. Wings, costal field with apices of branches of radial vein dilated; apical triangle present, small; anal field folded as a fan.

Abdomen. Supranal plate narrow, slightly indented medially between cerci (Figure 1c). Cerci long, tapering toward apex. Subgenital plate wide, with 2 elongated styles and a median projection between them, and tapered expansion on each lateral edge (Figures 1d, 1e, 1f). Left phallomere shaped as an inverted $\underline{\mathrm{U}}$ with arms subequal in size and shape (Figure 1g). Right phallomere hooked, with elongate and widened apex (Figure 1h). Median sclerite comma-shaped, tapering toward apex (Figure 1i).

Material examined. Holotype: ơ, Brazil, Amazonas, Manaus, Reserva Ducke, V.D. Tarli \& V. Linard cols.; Paratypes: 1 ơ, 12/VII/2011; 1 ơ, 30/VI/2010; 6 ơ and 6 o, 814/XI/2010; $17 \mathrm{O}^{\circ}$ and 5 o, 30/XI-5/XII/2010; 10 o and 1 o, 1112/VII/2011; 5 o and 4 o, 24-27/V/2011; 4 o and 3 o, 10-14/V/ 2011 (INPA); 1 o and 1 o, 30/XI-5/XII/2010 (MNRJ). All paratypes from same locality as holotype.

Etymology. The species name refers to the shape of the apex of the style.

Discussion. This species is similar to A. goiana (Rocha e Silva-Albuquerque, 1974) in the lateral configuration of the base of the subgenital plate (Figure 1d). It differs in the configuration of the styles and the genitalia (Figures 1g, 1h, 1i).

Amazonina spinostylata sp. nov.

General coloration light brown (Fig. 6b) Head with distinct dark-brown marks on the labrum, genae, and between insertion of antennae; dark-brown transverse stripe on interocular space (Figure 2a), antennae light-golden tomentose; pronotum hyaline, central disk milky light brown with dark-brown nuances (Figure 2b). Tegmina dark brown, hyaline, with sparse darkbrown dots. Legs pale, basal portion of most femoral and tibial spines dark brown; pulvilli whitish.

Dimensions of Holotype ơ. Total length: $14.2 \mathrm{~mm}$; Length of pronotum: $2.5 \mathrm{~mm}$; width of pronotum: $2.9 \mathrm{~mm}$; length of tegmen: $11.9 \mathrm{~mm}$; width of tegmen: $3.0 \mathrm{~mm}$.

Head triangular, vertex exposed beneath pronotum in dorsal view. Interocular space ample, about half of space between bases of antennae; antennae long, reaching beyond apex of abdomen; maxillary palpi with third and fourth articles subequal in length and larger than the remaining articles, fifth article dilated.

Thorax with pronotum subtrapezoidal, with rounded, slightly deflexed lateral flaps; central disk conspicuous. Legs spiny; fore femora, ventrocephalic margin with 4 spines, decreasing in size toward apex, plus 2 larger apical spines; ventrocaudal margin with robust median spine plus 3 spines on apical third and one apical; middle and hind femora with 4 to 6 well-spaced spines and one apical spine, similarly arranged on both ventral surfaces. Genicular spine present. Pulvilli tiny, present on all tarsomeres; claws symmetrical and specialized. Tegmina long, reaching beyond apex of cercus; marginal field narrow, approximately one-third length of tegmina; scapular
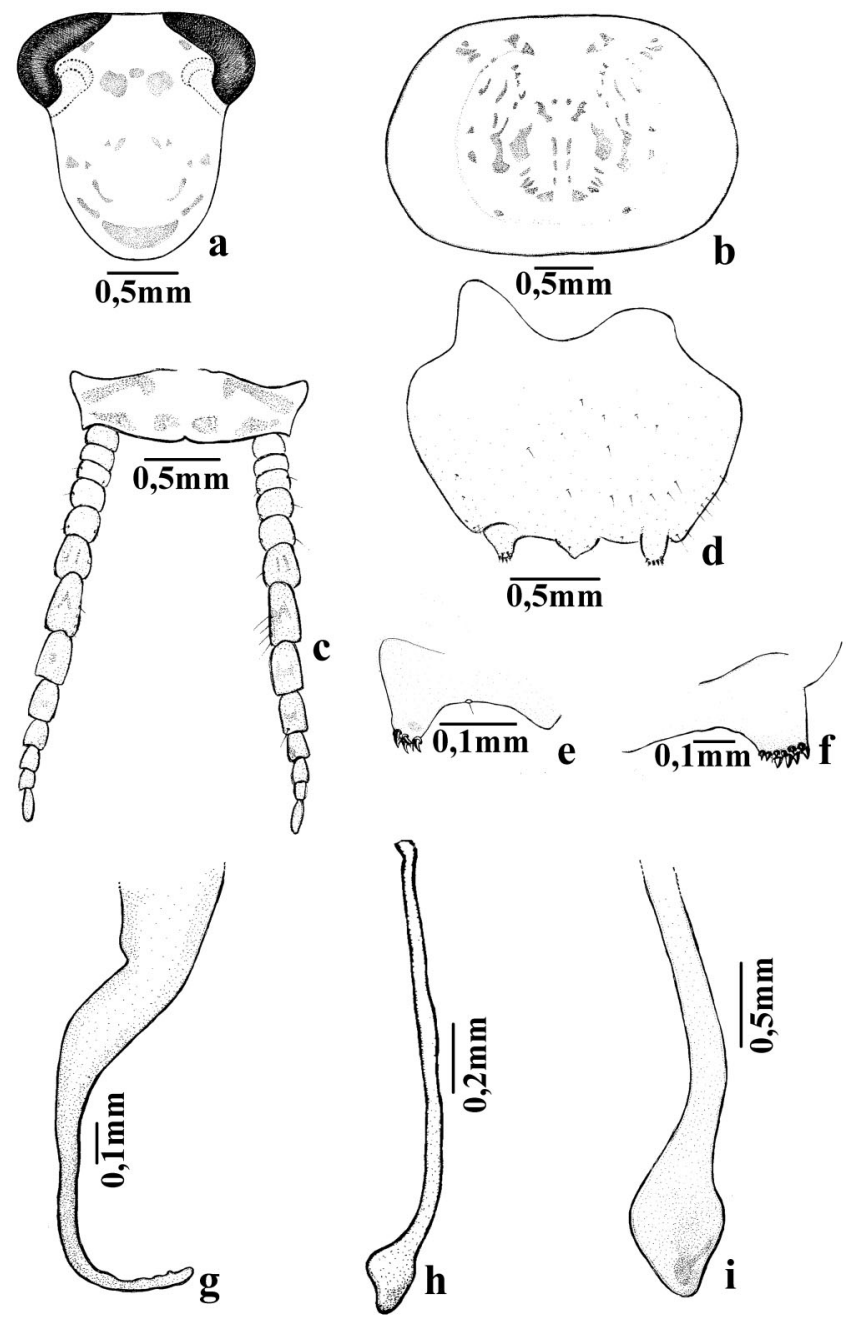

Figure 2. Amazonina spinostylata sp. nov., male holotype. a. Head, ventral view; b. Pronotum, dorsal view; c. Supranal plate, dorsal view; d. Subgenital plate, ventral view; e. Detail of the rounded left style with spiniform structures on apex, ventral view. f. Detail of the rounded right style with spiniform structures on apex, ventral view; g. Right phallomere, dorsal view; h. Median sclerite, dorsal view; i. Detail of apically spoon-shaped median sclerite, dorsal view.

field long, with oblique venules; discoidal field with longitudinal veins, radiating in such a way that basal branches appear oblique; anal field short and narrow, with four or five axillary veins.

Abdomen. Supranal plate narrow, with slight median indentation; cerci long and tapering toward apex (Figure 2c); subgenital plate symmetrical, with conspicuous triangular projection medially (Figure 2d); styles short, round, with spiny projections on apex (Figures 2e, 2f); right phallomere slender, hook-shaped, with slight projections apically (Figure $2 \mathrm{~g}$ ); median sclerite slender and spoon-shaped apically (Figures 2h, 2i).

Material examined. Holotype ơ, Brazil, Amazonas, Manaus, Reserva Ducke, 24-27/V/2012, V.D. Tarli \& V. Linard; Paratypes: 1 o", 10-14/V/2011; 14 o*, 30/XI-5/XII/ 2010; 8 ơ, 24-27/V/2011; 7 ơ, 10-14/V/2011 (INPA); 1 ○’, 1 ᄋ, 10-14/V/2011 (MNRJ). All paratypes from same locality as holotype.

Etymology. The species is named for the shape of the styles. 
Discussion. This species is similar to A. nodipenis (Hebard, 1926) in the configuration of the subgenital plate (Figure 2d) and styles (Figures 2e, 2f), differing in its general coloration (Figure 6b) and genitalia (Figures 2g, 2h, 2i).

\section{Cariblatta duckeniana sp. nov.}

General coloration brown (Fig. 6c). Head dark brown with vertex yellowish brown, interocular space dark brown (Figure 3a); eye black; antennae with seven light-brown basal antennomeres. Pronotum with central disk dark brown, lateral flaps hyaline (Figure 3b). Legs dark brown with whitish pulvilli. Tegmina bicolored, marginal field and outer stripe narrow and scapular field hyaline; anal and discoidal fields and inner stripe of scapular field dark brown.

Dimensions of Holotype o . Total length: $11.2 \mathrm{~mm}$; length of pronotum: $1.92 \mathrm{~mm}$; width of pronotum: $2.8 \mathrm{~mm}$; length of tegmen: $10.3 \mathrm{~mm}$; width of tegmen: $2.6 \mathrm{~mm}$.

Head subtriangular, vertex exposed beneath pronotum in dorsal view; interocular space narrow, approximately 1/4 space between antennal insertions; antennae long and tomentose, reaching beyond apex of abdomen; maxillary palpi tomentose, third article longer than fourth, fifth article dilated.

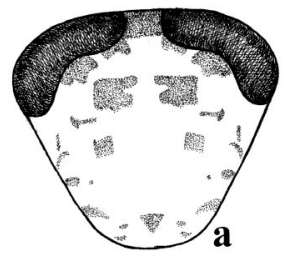

$\overline{0,5 \mathrm{~mm}}$
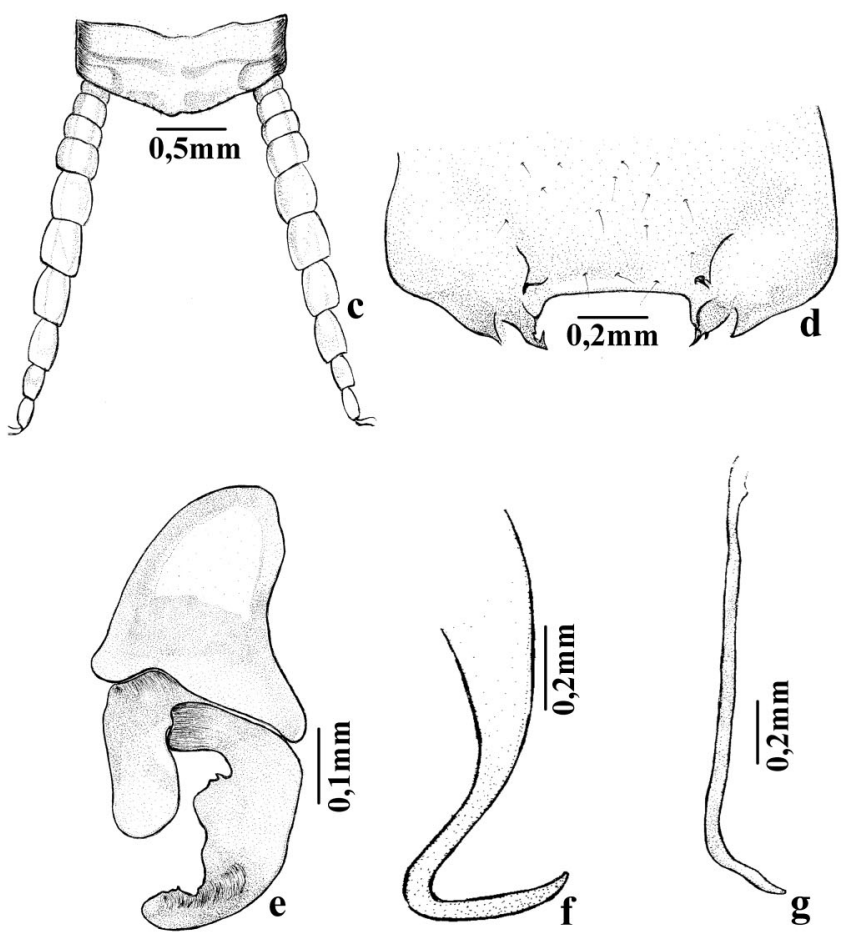

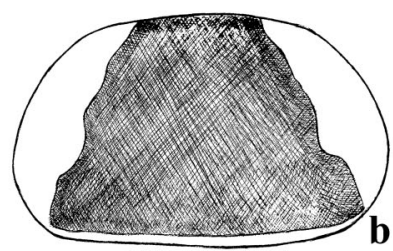

$\overline{0,5 \mathrm{~mm}}$
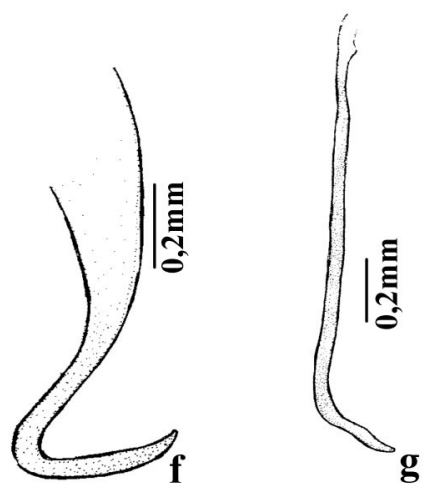

Figure 3. Cariblatta duckeniana sp. nov. male holotype. a. Head, ventral view; b. Pronotum, dorsal view; c. Supranal plate, dorsal view; d. Subgenital plate, ventral view; e. Left phallomere, dorsal view; f. Right phallomere, dorsal view; g. Median sclerite, dorsal view.
Thorax with pronotum subtrapezoidal, transverse, convex, with lateral flaps rounded and slightly deflexed; legs spiny. Fore femora with ventrocephalic margin bearing 12 spines that decrease in size toward apex, plus 2 larger apical spines; ventrocaudal margin with three spines on apical third, plus one apical spine. Middle and hind femora with 6 to 7 well-spaced spines up to apex, one apical spine, spines similar on both ventral surfaces. Middle and hind femora each with genicular spine; pulvilli present on all tarsomeres; claws symmetrical, specialized, with ventral denticles. Arolium present, small. Tegmina lanceolate, long, reaching beyond apex of cerci, marginal field narrow and long, reaching to midlength of tegmina; scapular field with oblique venules; discoidal field with longitudinal veins; anal field short, with four axillary veins. Wings with costal field having apices of branches of radial vein dilated; apical triangle present, small; anal field ample and folded as a fan.

Abdomen. Supranal plate narrow, with slight median indentation between cerci; cerci long, slightly dilated (Figure 3c); subgenital plate wide, base straight between styles; two projections present near base of plate, tapering toward apex, styles differentiated, bearing apical spine (Figure 3d); left phallomere shaped as inverted $\mathrm{U}$ with 2 arms differing in shape and size (Figure 3e); right phallomere hook-shaped, with preapical notch (Figure 3f); median sclerite long and slender at apex (Figure 3g).

Material examined. Holotype: ơ, Brazil, Amazonas, Manaus, Reserva Ducke, 10-14/V/2011, V.D. Tarli \& V. Linardi cols.; paratypes: 1 o", 30/XI-5/XII/2010; 2 o, 24-27/V/ 2011 (INPA); 1 ㅇ. All paratypes from same locality as holotype. No material deposited in Museu Nacional, UFRJ.

Etymology. The name of the species is derived from the type locality, the Reserva Ducke.

Discussion. This species can be distinguished from all other members of the genus by the shape of the subgenital plate (Figure 3d), differing in the general coloration (Figure 6c) and genitalia (Figures 3e, 3f, 3g).

\section{Cariblatta manauensis sp. nov.}

General coloration dark brown (Figure 6d); frons with dark-brown transverse stripe between bases of antennae; interocular space with slightly darker stripe; antennae yellowish dark brown, golden-tomentose (Figure 4a); pronotum hyaline with central disk milky with dark-brown marks, strokes and dots (Figure 4b). Legs with base of tibial spines and apex of tarsal articles dark brown. Tegmina hyaline with light brownish-orange veins and dark-brown transverse veins in median and apical regions of discoidal field.

Dimensions of Holotype o*. Total length: $13.9 \mathrm{~mm}$; length of pronotum: $2.6 \mathrm{~mm}$; width of pronotum: $3.1 \mathrm{~mm}$; length of tegmen: $11.7 \mathrm{~mm}$; width of tegmen: $3.1 \mathrm{~mm}$.

Head subtriangular, wide, vertex slightly exposed beneath pronotum in dorsal view; interocular space narrow, approximately 1/4 distance between bases of antennae; antennae long and tomentose, reaching beyond apex of abdomen; maxillary palps with third article longest, fifth article dilated.

Thorax with pronotum convex, subtriangular, lateral flaps and apex rounded. Legs spiny, fore femora with ventrocephalic margin armed with 16 spines, 6 decreasing in length toward apex, plus 2 apical spines; ventrocaudal margin with 2 spines on apical third, plus 1 apical spine; middle and hind femora with 4 or 5 spaced spines and 1 apical spine; spines similar on both 


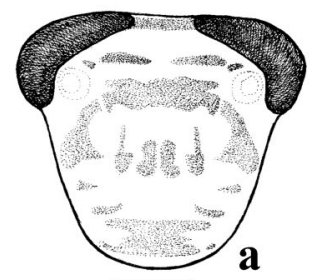

$\overline{\mathbf{0 , 5 m m}}$
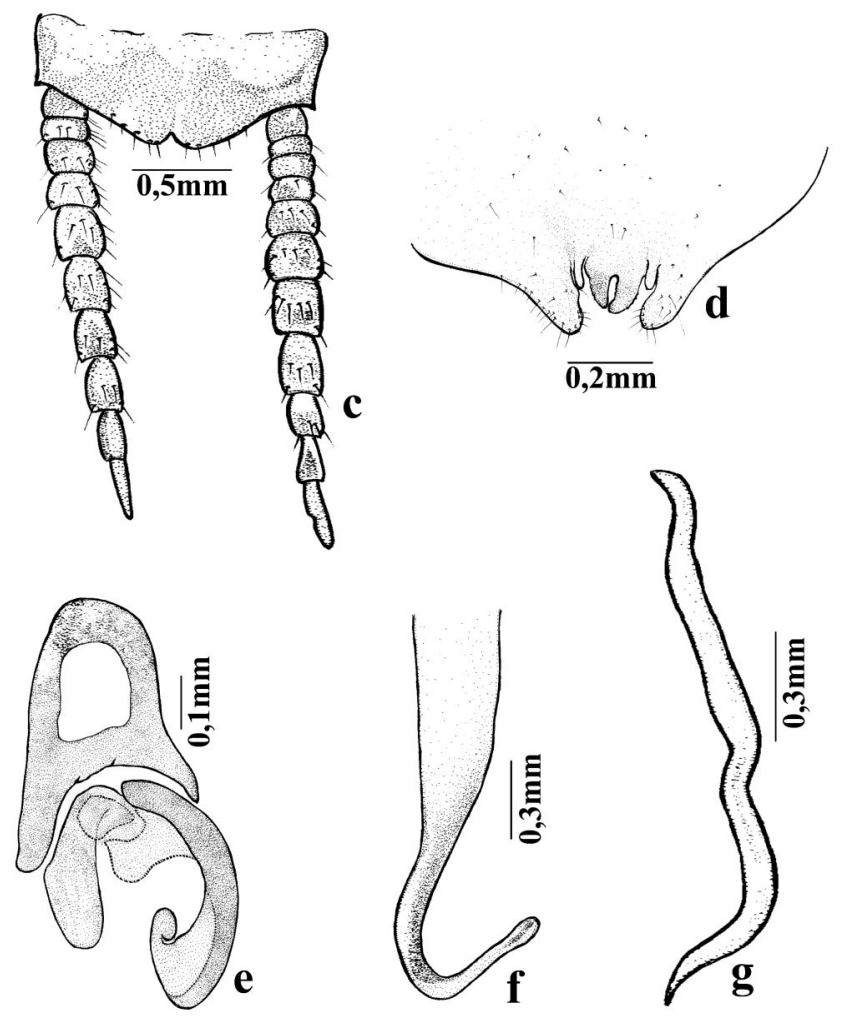

Figure 4. Cariblatta manauensis sp. nov. male holotype. a. Head, ventral view; b. Pronotum, dorsal view; c. Supranal plate, dorsal view; d. Subgenital plate, ventral view; e. Left phallomere, dorsal view; f. Right phallomere, dorsal view; g. Median sclerite, dorsal view.

ventral surfaces; pulvilli on all tarsomeres; claws symmetrical and specialized, with ventral denticles; arolia present. Tegmen lanceolate, marginal field narrow and deflexed; scapular field elongate, with oblique venules; discoidal field with veins arranged longitudinally; anal field short, with 6 to 7 axillary veins. Wings, costal field with apices of branches of radial vein dilated; apical triangle present, small; anal field ample and folded as a fan.

Abdomen. Supranal plate narrow, with distinct median indentation between cerci (Figure 4c); subgenital plate ventrally narrowing toward apex, with rounded extensions with median styliform notch, serrated internally, and with two smaller rounded styles (Figure 4d); left phallomere shaped as an inverted $\mathrm{U}$ with two arms differing in shape and size (Figure 4e); right phallomere hook-shaped with conspicuous pre-apical notch, apex elongate and round (Figure 4f); median sclerite long, its apex slender (Figure 4g).

Material examined. Holotype: Ơ, Brazil, Amazonas, Manaus, Reserva Ducke, 8-14/X/2010, V.D. Tarli \& V.
Linard cols.; paratypes: $10^{\circ}$ and 5 o, 8-14/XI/2010; 1 ơ and 7 ᄋ, 30/XI-5/XII/2010; 2 @, 11-12/VII/2011; 2 ९, 24-27/V/2011; 4 o, 10-14/V/2011 (INPA); 1 \%, 30/XI-5/XII/2010 (MNRJ). All paratypes from same locality as holotype.

Etymology. The specific name refers to the name of the city, Manaus, where the material was collected.

Discussion. This species is similar to C. vera (Rocha e SilvaAlbuquerque \& Lopes, 1975) differing in the configuration of the subgenital plate (Figure 4d).

\section{Nyctibora nigra sp. nov.}

General coloration dark brown, with yellowish dark-brown tomentosity (Figure 6e). Head brown (Figure 5a), eyes almost black; tip of clypeus light brown; palps and antennae goldentomentose with light-brown tips; ocelli whitish yellow; pronotum black (Figure 5b); legs dark, golden-tomentose with darkbrown spines; pulvilli whitish.

Dimension of Holotype ơ. Total length: $27.2 \mathrm{~mm}$; length of pronotum: $6.9 \mathrm{~mm}$; width of pronotum: $9.8 \mathrm{~mm}$; length of tegmen: $24.2 \mathrm{~mm}$; width of tegmen: $8.4 \mathrm{~mm}$.

Head subtriangular; vertex slightly exposed beneath pronotum in dorsal view; interocular space ample, measuring
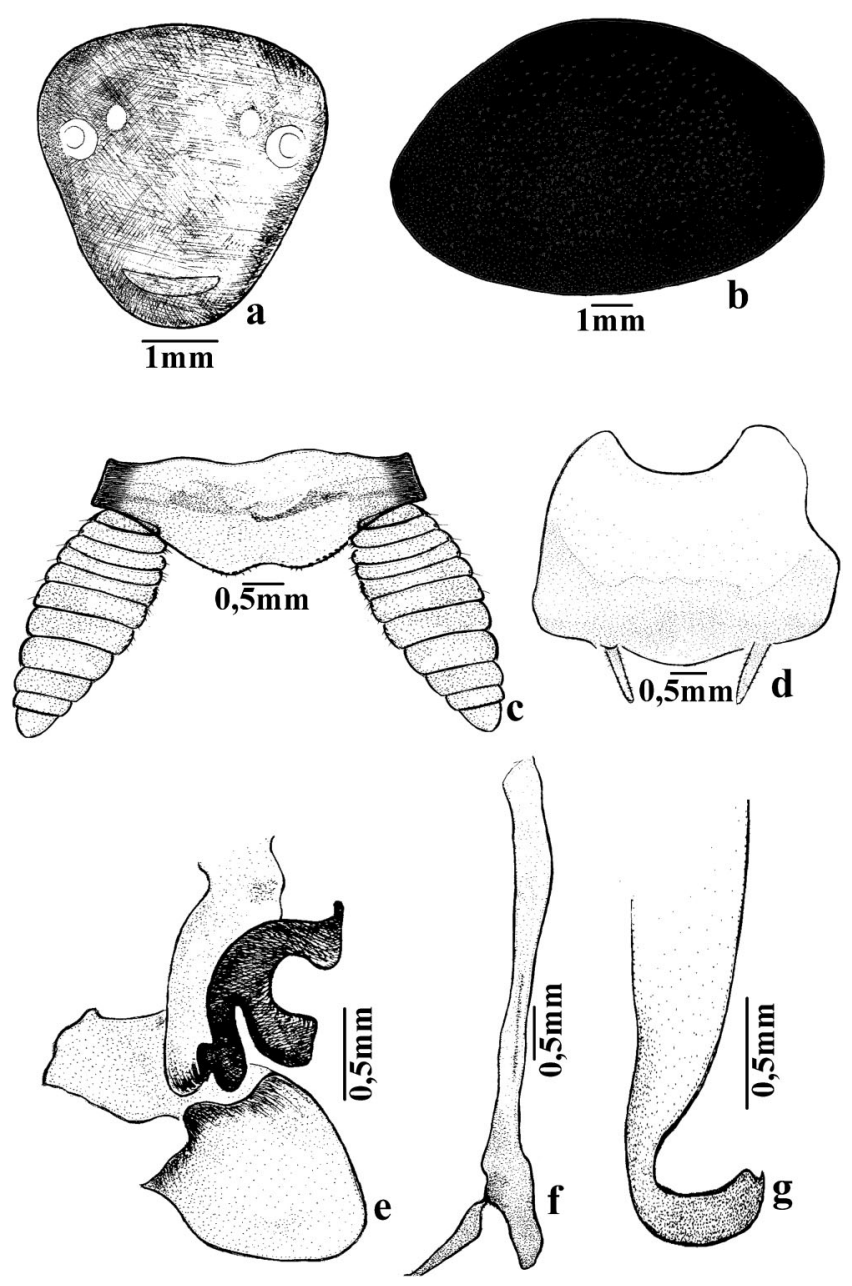

Figure 5. Nyctibora nigra sp. nov. male holotype. a. Head, ventral view; b. Pronotum, dorsal view; c. Supranal plate, dorsal view; d. Subgenital plate, ventral view; e. Right phallomere, dorsal view; f. Median sclerite, dorsal view; g. Left phallomere, dorsal view. 
Lopes S.M. et al.

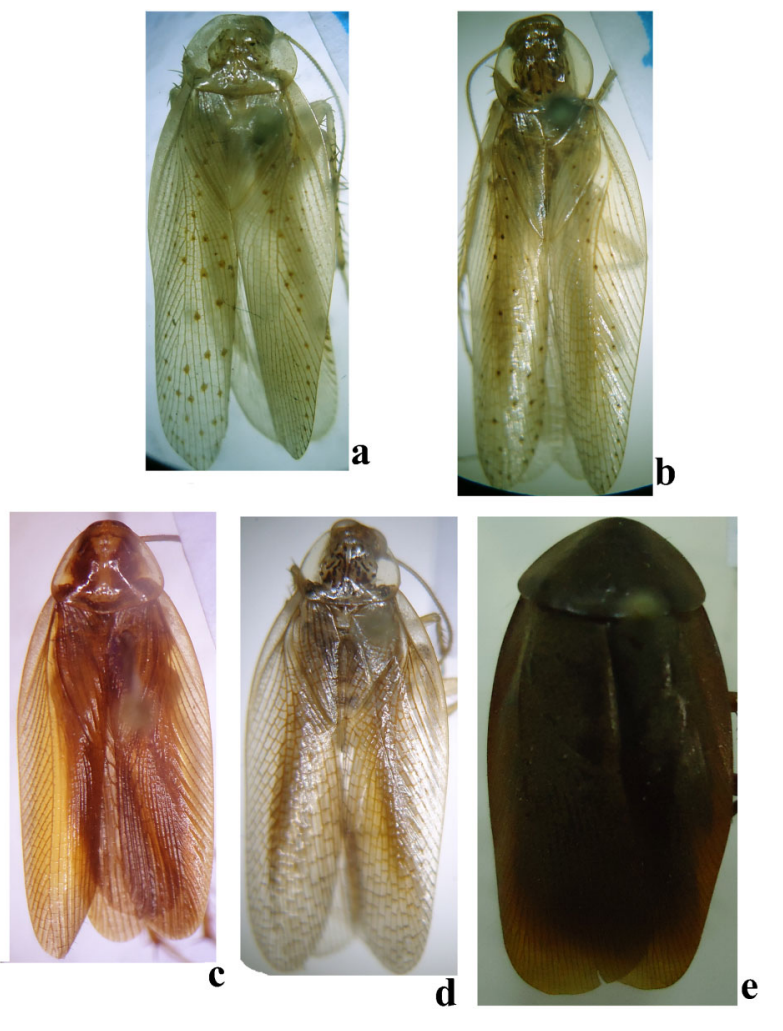

Figure 6. Habitus. a. Amazonina spiculata sp. nov., male holotype; b. Amazonina spinostylata sp. nov. male holotype; c. Cariblatta duckeniana sp. nov. male holotype; d. Cariblatta manauensis sp. nov. male holotype; e. Nyctibora nigra sp. nov. male holotype.

about half distance between bases of antennae; ocelli conspicuous; antennae long, reaching beyond apex of cerci; maxillary palps with four articles, each dilated at apex, and fifth article dilated and longer than remaining articles.

Thorax with pronotum elliptical, transverse and convex. Legs robust and tomentose; fore femora with ventrocephalic margin bearing small spines up to apex, pre-apical spine longest, and 2 larger apical spines; ventrocaudal margin with spines up to apex, with 1 spine on apical third, plus apical spine. Middle and hind femora with 6 to 9 robust, well-spaced spines, 1 apical spine; spines similar on both ventral surfaces; middle and hind femora each with genicular spine. Claws symmetrical, not specialized; arolia present; pulvilli present on all tarsomeres. Tegmina tomentose and developed, reaching beyond apex of cerci; marginal field narrow and elongate; scapular field with oblique venules; discoidal field ample, with longitudinal venules; anal field ample, with 11 axillary veins. Wings developed; apical triangle absent; anal field folded as a fan.

Abdomen. Supranal plate narrow proximally, distal half wider; inconspicuous indentation medially between cerci; cerci short, wide, tapering toward apex (Figure 5c); subgenital plate wide, short and asymmetrical, with apex slightly rounded and inconspicuous at the base between the styles, styles similar in shape and size (Figure 5d); right phallomere with laminar arms and sclerotized medially (Figure 5e); median sclerite long, wide at base, with slender medial-apical projection (Figure 5f); left phallomere hook-shaped (Figure $5 \mathrm{~g}$ ).

Material examined. Holotype: ơ, Brazil, Amazonas, Manaus, Reserva Ducke, 24-27/V/2011, V.D. Tarli \& V. Linard cols.; paratype: 1 o, same locality as holotype, 8-14/
XI/2010 (INPA). No material deposited in Museu Nacional/ UFRJ.

Etymology. The species epithet refers to the general coloration.

Discussion. This species differs from other members of the genus in size, coloration (Figure 6e), and the configuration of the genital plates (Figures $5 \mathrm{e}-\mathrm{g}$ ).

\section{Acknowledgments}

We are grateful to Prof. Solange Garrido for translation the text and to Dr. Janet W. Reid for edited the text in English.

\section{References}

BECCALONI, G.W. 2014. Cockroach Species File Online. Version 5.0/ 5.0. World Wide Web electronic publication. <http://Cockroach. SpeciesFile.org $>$ [accessed 29 July 2014].

BELL, W.J., ROTH, L.M. \& NALEPA, C.A. 2007. Cockroaches: Ecology, Behavior, and Natural History. The Johns Hopkins University Press. Baltimore, Maryland. 230p.

EISENBEIS, G. \& WICHARD, W. 1985. Atlas on the Biology of Soil Arthropods. Springer-Verlag, Berlin. 437p.

FITTKAU, E.J. \& KLINGE, H. 1973. On biomass and trophic structure of the central Amazonian rain forest ecosystem. Biotropica 5:2-14, http://dx.doi.org/10.2307/2989676

GURNEY, A.B., KRAMER, J P. \& STEYSKAL, G.C. 1964. Some Techniques for the Preparation, Study and Storage in Microvials of Insect Genitalia. Ann. Entomol. Soc. Am. 57: 240-242.

KAMBHAMPATI, S. 1996. Phylogenetic relationship among cockroach families inferred from mitochondrial $12 \mathrm{~S}$ rRNA gene sequence. Syst. Entomol. 21: 89-98.

LOPES, S.M. 2008. Espécie nova de Amazonina e novo status para $A$. sooretamensis (Blattaria: Blattellidae: Pseudophyllodromiinae). Rev. Bras. Zool. 25(3): 499-501, http://dx.doi.org/10.1590/S010181752008000300015

LOPES, S.M. \& OLIVEIRA, E.H. 2000. Espécie nova de Blaberus Serville, 1831 do Estado de São Paulo, Brasil (Blaberidae, Blaberinae). Bol. Mus. Nac., Nova Sér., Zool. 415: 1-4.

LOPES, S.M. \& OLIVEIRA, E.H. 2002a. Espécie nova de Amazonina de Minas Gerais, Brasil (Blattaria, Blattellidae). Iheringia, Sér. Zool. 92(2): 5-8, http://dx.doi.org/10.1590/S0073-47212002000200001

LOPES, S.M. \& OLIVEIRA, E.H. 2002b. Espécies novas de Cariblatta Hebard, 1916 (Dictyoptera, Blattaria) de Mato Grosso, Brasil. Bol. Mus. Nac., Nova Sér., Zool. 480: 1-8.

LOPES, S.M. \& OLIVEIRA, E.H. 2004. Duas espécies novas de Cariblatta Hebard, 1916 (Blattaria, Blattellidae) do Estado do Acre (Brasil) coletadas em ninhos de vespas (Hymenoptera, Sphecidae). Arq. Mus. Nac. 62(2): 173-177.

LOPES, S.M. \& OLIVEIRA, E.H. 2005. Espécie nova de Cariblatta Hebard, 1916 (Blattaria, Blattellidae) do Estado do Mato Grosso, Brasil. Arq. Mus. Nac. 63: 639-641.

LOPES, S.M. \& OLIVEIRA, E.H. 2009. Espécies e registros novos de Nyctibora Burmeister, 1838 do Brasil e considerações sobre o gênero (Blattaria: Blattellidae). Lundiana 9(1): 49-51.

MAEKAWA, K. \& MATSUMOTO, T. 1999. Molecular phylogeny of cockroaches (Blattaria) based on mitochondrial COII gene sequences. Syst. Entomol. 25: 511-519, http://dx.doi.org/10.1046/ j.1365-3113.2000.00128.x

RENTZ, D.C.. 2014. A guide to the cockroaches of Australia. CSIRO Publishing, Collingwood. 318p.

RIBEIRO, J.E.L.S., HOPKINS, M.J.G., VICENTINI, A., SOTHERS, C.A., COSTA, M.A.S., BRITO, J.M., SOUZA, M.A.D., MARTINS, L.H.P., LOHMANN, L.G., ASSUNÇÃO, P.A.C.L., PEREIRA, E.C., SILVA, C.F., MESQUITA, M.R. \& PROCÓPIO, L.C. 1999. Flora da Reserva Ducke: Guia de identificação das plantas vasculares de uma floresta de terra-firme 
na Amazônia Central. Instituto Nacional de Pesquisas da Amazônia, Manaus, Amazonas. 816p.

ROCHA E SILVA ALBUQUERQUE, I. 1974. Revisão do gênero Amazonina Hebard, 1929 (Epilampridae, Blattellinae). Acta Amazonica 4(2): 55-67.

ROCHA E SILVA ALBUQUERQUE, I. \& LOPES, S.M. 1975. Revisão de Cariblatta Hebard, 1916 no Brasil (Dictyoptera, Epilampridae, Blattellinae). Rev. Bras. Biol. 35(2): 273-396.
ROTH, L.M. 2003. Systematics and phylogeny of cockroaches (Dictyoptera: Blattaria). Oriental Insects 3: 1-186.

SAMPAIO, P. de T.B., BARBOSA, A.P., VIEIRA, G., SPIONELLO, W.R. \& BUENO, F.M.S. 2005. Biomassa da rebrota de copas de pau-rosa (Aniba rosaeodora Ducke em plantios sob combra parcial em floresta primária. Acta Amazonica 35(4): 491-494.

VÉLEZ-BRAVO, A. 2013. Checklist of Colombian cockroaches (Dictyoptera, Blattaria). Biota Colombiana 9(1): 21-38.

Received 03/12/2013

Revised 13/10/2014

Accepted 15/10/2014 